\title{
Development and deployment of autonomous water level monitoring system in the lower and upper sections of the Slyudyanka River
}

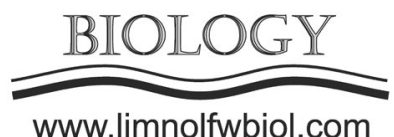

\author{
Aslamov I.A.*๑, Makarov M.M. ${ }^{\oplus}$, Gnatovsky R.Yu., Chernyshov M.S., Kucher K.M.
}

Limnological Institute, Siberian Branch of the Russian Academy of Sciences, Ulan-Batorskaya Str., 3, Irkutsk, 664033, Russia

\begin{abstract}
The article presents the autonomous hydrometeorological station for organizing networks of monitoring the hydrological conditions in water bodies and collecting the related information, such as meteorological, hydrophysical, etc. The station showed high autonomy and accuracy in measuring water level in a water body. It also has an integrated GSM module for remote data transmission. It was successfully tested during a trial installation on the Slyudyanka River (Lake Baikal basin) in the autumn of 2020, which allowed us to characterize the behaviour of the main hydrological parameters of the watercourse.
\end{abstract}

Keywords: automated hydrometeorological station, river runoff, water level, Slyudyanka River, monitoring, Lake Baikal

\section{Introduction}

The problem of creating an integrated monitoring system for inland catastrophic hydrological phenomena is longstanding, and recent years have only confirmed it. The frequency of floods increases from century to century (Avakyan and Istomina, 2013), and due to the reduction of observation sites and limited instrumentation, the forecast of hazardous phenomena associated with a rise in the level of river waters becomes even more difficult. A comprehensive characterization of the flood hazard in the rivers of the Baikal region was described in (Kichigina, 2018). The catastrophic floods of 2019 in East Siberia is direct evidence of the severe negative consequences of such phenomena (Shalikovsky et al., 2019). Despite the obvious risks, coastal areas are still the most attractive for development in terms of economic activity.

In this situation, the development of the station that would be able to predict the occurrence of hazardous phenomena and characterize the behaviour of the main hydrological parameters of the investigated watercourses in an autonomous mode is the optimal solution of the problem of monitoring the hydrological conditions. To develop the algorithm for obtaining data on the water level regime in rivers and their further application for mathematical modelling, we organized the automated monitoring of water level in the upper and lower sections of the Slyudyanka River (Southern Baikal) using our automated stations designed at Limnological Institute SB RAS.

\section{Materials and methods}

To solve the problem of monitoring the hydrological conditions in rivers, researchers from Laboratory of Hydrology and Hydrophysics at Limnological Institute SB RAS developed an automated hydrometeorological station (AHMS) (Makarov et al., 2018). The station is designed to organize network for monitoring the hydrological conditions in water bodies and collect related information: meteorological, hydrophysical, etc. The measured environmental parameters are transmitted in real time or for certain periods via wireless communication channels to a remote Internet server. Functionally, this server with an external IP address is a data collection and data processing centre (data centre). Tasks of the data centre include receiving data from the network of monitoring stations, primary processing, storage and provision of the access through the web page (https://hlserver.lin. irk.ru/shs/monitor/).

A Microchip microcontroller with a 16-bit architecture, which is the link connecting all elements, sets the logic of the AHMS operation. A GSM terminal is integrated into the device for data transmission to the Internet. In the absence of cellular networks in the area of AHMS setup, it is possible to connect GlobalStar or Iridium satellite terminals or operate in fully autonomous mode, saving the collected data at the removable non-volatile memory SD card. Since the memory card is formatted in FAT32, the recorded data can be read from any operating system without 
using specialized software. To ensure the unity of time between stations and measurements synchronization, the device has an integrated ML8088s receiver of geographical coordinates (manufactured by NAVIA company, Russia), which provides a binding to the atomic clock of the GLONASS and GPS satellites. The station is powered by $12 \mathrm{~V}$ lead-acid battery and charged from a $30 \mathrm{~W}$ solar panel. A charge controller is integrated into the power supply circuit, which maintains the optimal charging voltage depending on the temperature of the batteries and protects them from overcharge and deep discharge, which significantly extends the service life. The presence of external I2C and COM ports in the device, as well as additional analogue input channels, provide the possibilities of its adaptable expansion: equipping with additional sensors and connecting external equipment.

The water level is determined by hydrostatic pressure measurement with software atmosphere pressure compensation. A high-precision digital pressure sensor developed in Laboratory of Hydrology and Hydrophysics at Limnological Institute SB RAS is a sensitive element for measuring the water level. The resolution of the sensor is about $0.2 \mathrm{~mm}$ of water column.

Meteorological parameters are measured with a set of Vantage Pro 2 sensors, Davis Instruments, USA (Vantage Pro2 Specification Sheets). The basic set includes the following sensors: air temperature, air humidity, atmospheric pressure, wind speed and direction, and precipitation sensor. The extended set is complemented with solar radiation and ultraviolet radiation sensors.

With hydrostatic pressure level sensors, the developed AHMS yields much more accurate (up to 0.2 $\mathrm{mm}$ ) and high frequency measurements (with up to 5 $\mathrm{Hz}$ sampling frequency) of water level and atmospheric pressure with a precise timing received from GLONASS and GPS satellites. In terms of water level measurement accuracy, AHMS corresponds to the world's best analogues (e.g. the Orpheus Mini sensor manufactured by OTT Hydromet GmbH or the EHP-CMC system manufactured by EHP-Tekniikka Ltd.), and in terms of recording high frequency oscillations (with periods of less than a minute), it surpasses them. The results of measurements from the network of such stations and their integration into a single system for monitoring the ecological condition in Baikal natural territory will allow us to receive up-to-date information in real time and perform a reliable interpretation of the results.

The economic advantage of AHMS is its unpretentiousness, without additional maintenance by a person. Power from solar panels eliminates the cost of energy supply, and the cost of data transmission via cellular communication channels, as a rule, does not exceed one thousand rubles per year.

\section{Study site}

The Slyudyanka River is one of the many tributaries of South Baikal, runs down from the northern slope of the Khamar-Daban ridge and has a mountainous nature. Due to the small distance of the ridge axis to the lake coast (about 25-30 km), Slyudyanka is characterized by a small drainage area - $73.3 \mathrm{~km}^{2}$. The difference in elevation between the source and the mouth of the river is about $1100 \mathrm{~m}$, with the length of the main channel of $21 \mathrm{~km}$. Its average flow rate is $0.71 \mathrm{~m}^{3} / \mathrm{s}$.

On 19 September 2020, we installed AHMS at two sections of the Slyudyanka River. The first station (Lower section) was located at a distance of $5 \mathrm{~km}$ from the site where the river inflows to Lake Baikal, the coordinate of $51.62939 \mathrm{~N} 103.67485 \mathrm{E}$ (Fig. 1). The second station (Upper section) was installed upstream, at a distance of $8.5 \mathrm{~km}$ from the first station, the coordinate of $51.57230 \mathrm{~N} 103.62080 \mathrm{E}$. Height above sea level in the Baltic height system was $589 \mathrm{~m}$ for the lower station and $954 \mathrm{~m}$ for the upper station. On 22 October 2020, we removed the stations after two cases of freezing of the level sensors. The stations were powered only from lead batteries as a testing regime.

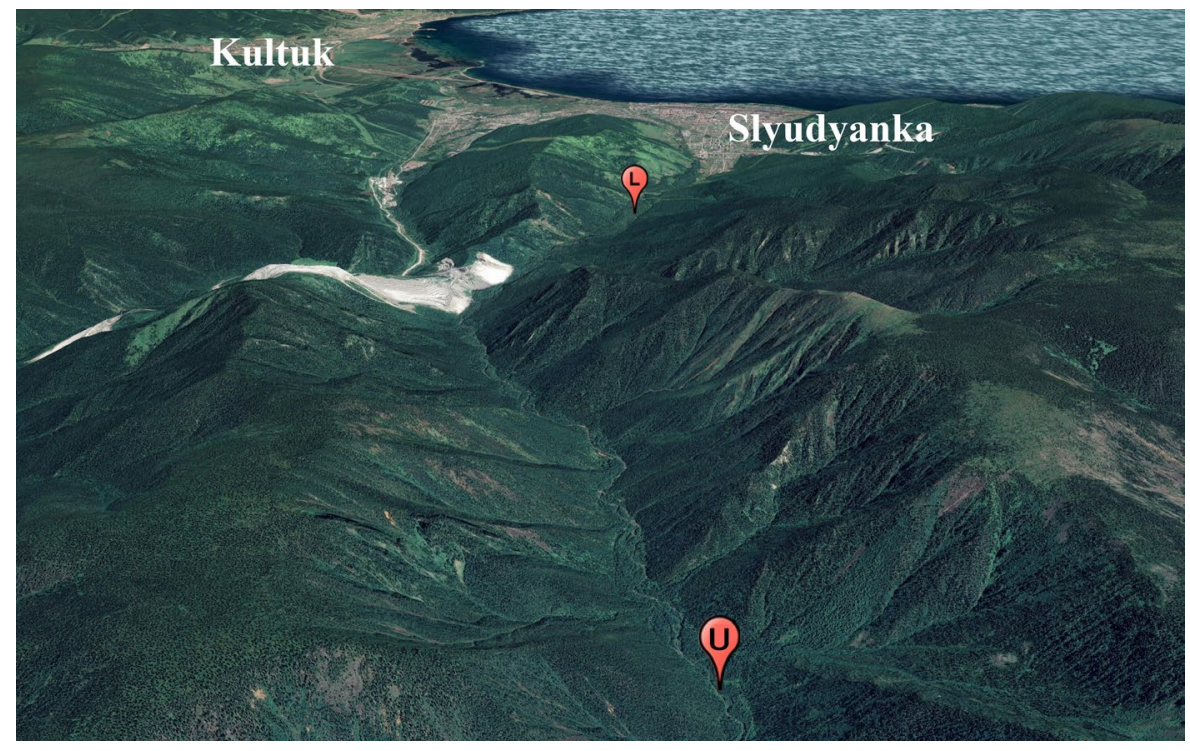

Fig.1. Sites of AHMS installation on the Slyudyanka River. 


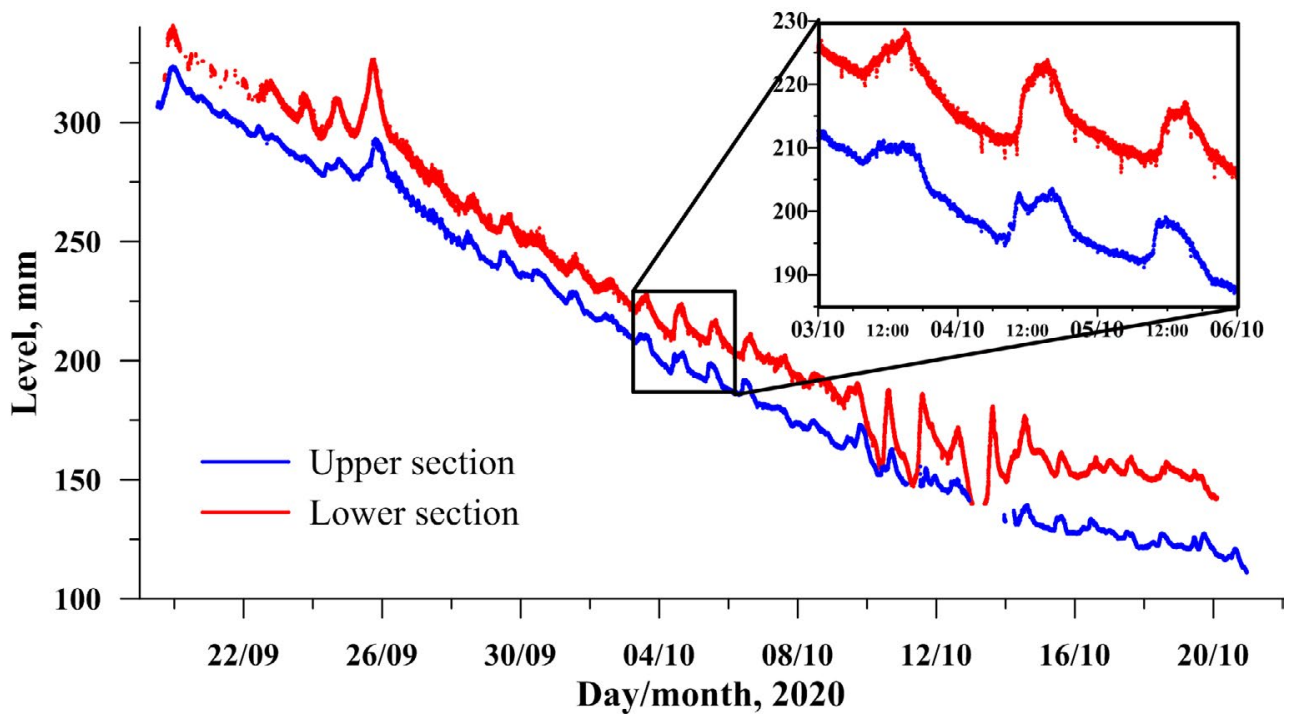

Fig.2. Comparison of data on the water level in the Slyudyanka River at two sections.

Therefore, to save battery power, the obtained data were transmitted every four hours. The upper station was equipped with a set of meteorological sensors, which allowed us to track the main meteorological parameters. The stations were installed without tide gauge wells, therefore, water level fluctuations were filtered by a digital method, through averaging measurements of level during 30-second period, which were carried out every two minutes to save electricity.

\section{Results and discussion}

The obtained data on the water level at both stations for the entire observation period are shown on Fig. 2. The stations were installed after heavy rains in the first half of September, and during their operation, the water level in the river gradually decreased. On average, during a month, both in the upper and lower sections, the water level decreased by approximately $200 \mathrm{~mm}$.

A detailed analysis of the data on the water level at the two stations has revealed that in both sections, the water level experiences diurnal fluctuations with an amplitude from 5 to $10 \mathrm{~mm}$, which are not associated with precipitation. The daily maximum of the water level lags behind the noon of the local time and occurs approximately at 14 or 15 o'clock (see inset in Fig 2). Analysis of the data did not allow us to estimate the delay time between stations because the daily rise in the water level at the lower station usually began earlier than at the upper one, but, at the same time, it was more extended in time. At the upper station, respectively, the water level rise took place later. We think that this is due to a huge number of streams flowing into the river in the area from the upper station to the lower one. Consequently, the streams flowing into the Slyudyanka River downstream thaw out and affect the lower station earlier than the upper station.

Unfortunately, there was no significant precipitation during the operation of AHMS, and at the upper station, precipitation fell in the form of snow. In 2021, we plan to install the stations at the onset of the spring season, after snowmelt and breakup of river ice, to study the period of filling the river bed with water.

\section{Conclusions}

The automated hydrometeorological station (AHMS) developed at Limnological Institute SB RAS showed high autonomy and accuracy in measuring the water level. It proved its worth at Lake Baikal, working throughout the year and receiving energy from $30 \mathrm{~W}$ solar panels. And it was successfully tested during a trial installation on the Slyudyanka River in the autumn of 2020, but it had to be removed with the onset of cold weather. The hydrostatic method and a highly sensitive pressure sensor ensure high water level measurement accuracy. However, as wee see, this method is not suitable for rivers. Many rivers freeze completely in the winter and have flood events, during which water carries fragments of trees, stones, etc. Such debris will inevitably damage the sensor installed at the river bottom or underwater communication cable. Taking into account the above specifics of the station installation on the river, it is necessary to modernize it, in particular, to replace the sensor with a non-contact radiowave radar level meter of the ULM-31A1-HF-LC type (manufactured by LiMako company, Russia).

\section{Acknowledgements}

The work was supported by the grant No. 07515-2020-787 in the form of a subsidy for a Major scientific project from Ministry of Science and Higher Education of Russia (project "Fundamentals, methods and technologies for digital monitoring and forecasting of the environmental situation on the Baikal natural territory"). 


\section{Conflicts of Interest}

The authors declare no conflicts of interest.

\section{References}

Avakyan A.B., Istomina M.N. 2013. Floods as a global problem. Strategiya Grazhdanskoy Zashchity: Problemy i Issledovaniya. [Civil Protection Strategy: Problems and Research] 1: 180-193. (in Russian)

Kichigina N.V. 2018. Flood hazard on the rivers of the Baikal region. Geography and Natural Resources 39: 120-129. DOI: $10.1134 /$ S187537281802004X

Makarov M.M., Kucher K.M., Aslamov I.A. et al. 2018. The monitoring system of hydrophysical and hydrochemical parameters of Lake Baikal. Mezhdunarodnyy Zhurnal Prikladnykh i Fundamental'nykh Issledovaniy [Journal of Applied and Fundamental Sciences] 12(1): 120-124. DOI: 10.17513/mjpfi.12533 (in Russian)

Shalikovsky A.V., Lepikhin A.P., Tiunov A.A. et al. 2019. The 2019 floods in Irkutsk region. Vodnoye Khozyajstvo Rossii: Problemy, Tekhnologii, Upravleniye [Water Sector in Russia: Problems, Technologies, Management] 6: 48-65. (in Russian)

$\begin{array}{cccl}\begin{array}{c}\text { Vantage } \\ \text { Davis }\end{array} & \text { Pro2 } & \text { Specification } & \text { Sheets // } \\ \text { Instruments. } & \text { URL: } & \text { https://www. }\end{array}$
davisinstruments.com/product_documents/weather/ spec_sheets/6152_62_53_63_SS.pdf 